\title{
GOURT PAGKING REVISITED: A PROPOSAL FOR RATIONALIZING THE TIMING OF APPOINTMENTS TO THE SUPREME COURT
}

\author{
JOHN M. LAWLOR ${ }^{\dagger}$
}

The 1984 presidential election campaign resounded with references to the future of the Supreme Court. ${ }^{1}$ In view of the advanced age of a number of the current Justices, ${ }^{2}$ many commentators speculated that the winner of the election would make several appointments in the upcoming term. ${ }^{\mathbf{s}}$

An uneven distribution of appointment opportunities among Presidents is a natural consequence of the existing governmental structure. Under the Constitution, the President has the power to "nominate, and by and with the Advice and Consent of the Senate, [to] appoint . . . Judges of the supreme Court." Once appointed, these judges "hold their Offices during good Behaviour"s and receive compensation that may not be "diminished during their Continuance in Office." Thus, in the absence of changes in the size or structure of the Court, appointments arise simply as Justices resign, retire, or pass away. ${ }^{7}$ Under this

† B.A. 1979, Amherst College; J.D. Candidate 1986, University of Pennsylvania.

1 See, e.g., Schwartz, Rehnquist's Partisan Intrusion, N.Y. Times, Oct. 26, 1984, at 35, col. 2 (referring to Supreme Court appointments as "one of the most controversial issues in a hotly fought political campaign"); Greenhouse, Rehnquist Asserts Most Attempts By Presidents to Pack Court Fail, N.Y. Times, Oct. 20, 1984, at 1, col. 6 (describing "the age of the Justices and the likelihood that the next President will fill several vacancies" as campaign issues). But $c f$. L. TRIBE, GoD SAve This HonoraBLE CouRT at ix (1985) ("II]t is unlikely that the election reflected, in any decisive way, the considered views of more than a handful of the American people about the sorts of Justices they would want [the next President] to nominate."); Kaplan, The Campaign and the Court, Nat'l L.J., Nov. 5, 1984, at 6, col. 1 (suggesting that the presidential candidates themselves placed relatively little emphasis on the issue).

2 The members of the present Court have an average age of nearly 72 years. If no new appointments are made prior to November 3, 1986, this Court will become the oldest in the history of the nation, surpassing the Court that presided during the first term of Franklin Roosevelt. See L. TRIBE, supra note 1, at xv.

s See, e.g., Schwartz, supra note 1, at 35, col. 2; Taylor, Next President Could Shape Supreme Court for Generations, L.A. Daily J., Oct. 25, 1984, at 4, col. 3; Greenhouse, supra note 1, at 1, col. 6; see also L. TRIBE, supra note 1, at xviii ("IT]he aging of the Justices signals a potential constitutional revolution in the making."); Kaplan, supra note 1 , at 6, col. 1 (noting that only eight of the past 93 Justices served beyond the age of 80 ).

- U.S. Const. art. II, $\S 2$, cl. 2.

Id. art. III, § 1 .

- Id.

7 Statutory provisions governing the retirement and resignation of Supreme Court 
system some Presidents appoint an unusually large number of Justices, ${ }^{8}$ while others make disproportionately few appointments during their time in office. ${ }^{\circ}$

On several occasions during the nation's first eighty years, Congress altered the frequency of appointment opportunities by changing the number of Justices seated on the Court. ${ }^{10}$ The last of these changes, however, occurred in 1869.11 The constancy of the Court's nine-member size since that time, reinforced by the rejection of Franklin Roosevelt's attempt to "pack the Court,"12 has left the nation with an entrenched and largely unquestioned adherence to the current method of determining the frequency of appointments.

In the wake of this historical development, the essentially random timing ${ }^{13}$ of appointments has undergone relatively little scrutiny. ${ }^{14}$ The

Justices and other federal judges are set forth at 28 U.S.C. $\S \S 371-376$ (1982).

8 For example, Presidents Washington, Franklin Roosevelt, and Taft appointed eleven, nine, and six Justices, respectively. See McKay, Selection of United States Supreme Court Justices, 9 KAN. L. Rev. 109, 121 n.50 (1960). One of the appointments made by each of these Presidents was the elevation of an Associate Justice to the position of Chief Justice. See G. Gunther, Constitutional Law app. A (10th ed. 1980 \& Supp. 1984).

The greatest frequency of appointments occurred during Warren G. Harding's administration. Within the three years preceding his untimely death, President Harding appointed a total of four Justices to the Court. See id. Two of the four appointees-Justices Sutherland and Butler-were among the "Four Horsemen," the Justices who most vigorously resisted New Deal legislation in the years preceding the 1937 court-packing plan. See L. TRIBE, supra note 1, at 66-67.

- For example, Presidents Harrison, Taylor, Andrew Johnson, and Carter did not make any appointments during their terms in office, and nine Presidents made only one appointment. See G. GuNTHER, supra note 8, at app. A. As of 1981, the average number of appointments per President was 2.7, and the average number of appointments per four-year term was 2.2. See id.

The concern of the Democratic party in the 1984 election undoubtedly reflected both the number of appointment opportunities that the incumbent Republican President might have if re-elected and the relative paucity of appointments arising during prior Democratic administrations. Democrats controlled the presidency during three of the five terms immediately preceding President Reagan's inauguration in 1981. During the same period, Republican Presidents made five Supreme Court appointments, and the Democrats made four. See id. In addition, two of the four Justices appointed by Democrats resigned within four years of their appointment. As a result, only two of the seven Justices remaining from this period were appointed by Democrats, despite the relative success of the party in presidential elections. See id.

10 See McKay, supra note 8, at 116.

11 See Act of Apr. 10, 1869, ch. 22, § 1, 16 Stat. 44, 44 (current version at 28 U.S.C. $\S 1$ (1982)) ("[T]he Supreme Court . . . shall hereafter consist of the Chief Justice ... and eight associate justices ....").

12 See infra notes 38.46 and accompanying text.

1s Justices might exercise limited control over the process by timing their retirement with reference to political changes in the executive and legislative branches. Bob Woodward and Scott Armstrong, among others, have described Justice William O. Douglas's struggle to remain on the bench despite having suffered a serious stroke. See B. Woodward \& S. Armstrong, The Brethren 422-68 (1979). Particularly com- 
attention that the subject does receive usually focuses on the political branches' past attempts to "pack" the Court in order to achieve particular political ends. As a result, the possibility of change in the frequency of appointments has become inextricably associated with partisan threats to the independence of the Court.

In this Comment, I attempt to place court packing in a more sympathetic light. ${ }^{15}$ Part I briefly reviews the history of prior attempts to

pelling is their account of a conversation between Justice Douglas and his friend, Charles Reich:

"Bill, you must resign," Reich told him.

No, Douglas replied. "There will be no one on the Court who cares for blacks, Chicanos, defendants, and the environment." Even half functioning, he said, he would be better than no one. If he were to resign, Ford would name his replacement. That person would obviously be on the wrong side. Better to hang on, he said. "Even if I'm half dead, maybe it will make a difference about someone getting an education."

Id. at 463. Douglas reportedly claimed, however, that "[i]t didn't matter who was President, or from what party .... Whoever it was would be someone who would not care." Id.

Approximately half of all Justices have died during their tenure on the Court. See G. GuNTHER, supra note 8, at app. A. Others, like Justice Douglas, were too ill at the time of their retirement to have an option of continuing service into another term. At least some of the Justices, however, have presumably considered the likely ideological views of their replacements on the Court in deciding when to retire. But cf. Greenhouse, Better To Go Too Soon, N.Y. Times, June 20, 1981, at 9, col. 3 (reporting Justice Stewart's observations at the time of his retirement).

14 A number of recent studies in the area accept the present allocation of appointments as given and focus on other aspects of the appointment process, such as the Senate's role of advice and consent. See, e.g., L. TRIBE, supra note 1, at 77-92, 125-37; Black, A Note on Senatorial Consideration of Supreme Court Nominees, 79 YaLE L.J. 657, 658-61 (1970); McKay, supra note 8, at 128-33; Rees, Questions for Supreme Court Nominees at Confirmation Hearings: Excluding the Constitution, $17 \mathrm{GA}_{\mathrm{A}}$. L. REv. 913, 943-47 (1983); Note, Recess Appointments to the Supreme Court-Constitutional But Unwise?, 10 STAN. L. REv. 124, 145-47 (1957). Other studies consider the allocation of appointments only in reference to specific incidents of "court packing." See, e.g., Feinberg, Constraining "The Least Dangerous Branch": The Tradition of Attacks on Judicial Power, 59 N.Y.U. L. REv. 252, 264-65 (1984); Saylor, "Court Packing" Prior to FDR, 20 BAYLoR L. REv. 147, 164-65 (1968). But see Collier, The Supreme Court and the Principle of Rotation in Office, 6 GEo. WASH. L. REv. 401, 419 (1938) (proposing, in part, that the term of each Justice be fixed at 12 years); cf. Peck, Can Presidents Pack the Court?, UPDATE, Spring 1984, at 13 (accepting the allocation of appointments as given and focusing on Presidents' abilities to predict the voting records of their nominees).

${ }_{18}$ This Comment focuses in particular on appointments to the Supreme Court. The larger number of judges sitting on the district and appellate courts tends to reduce variations in the frequency of appointments at those levels. Moreover, the special legal and symbolic importance of the Supreme Court's decisions warrants a particular concern with the manner in which appointments for that court are allocated. $C f$. $\mathrm{M}$. Perry, The Constitution, the Courts, and Human Rights 4 (1982) (referring to the Court's "preeminent position in the American judiciary-a position of formal leadership with respect to certain matters, but also of informal leadership with respect to many more"). Nevertheless, additional study may very well be warranted with respect to variations in the frequency of appointments to the lower federal courts. A 
change the frequency with which Justices are appointed to the Court. I suggest that, although concerns about court packing are well grounded in history, the relatively long-standing tradition of a nine-member Court should not preclude a reconsideration of the problems associated with randomly allocated appointments.

Part II sets forth three criteria-independence, legitimacy, and competence-for assessing various methods of replenishing the Court's membership. Focusing in particular on the relationship between the first two criteria, I argue that the current system significantly weakens the legitimacy of the Court and thus its independence.

In Part III, I review various alternatives to the current system of appointments and propose a system in which nine becomes the equilibrium point, rather than the invariably fixed size, of the Court's membership. Under this system, the Court's size would increase temporarily if no appointment opportunities arise within the first three years of any presidential term. Following the next retirement, resignation, or death of a Justice, however, no appointment would be made, and the Court would return to its previous size.

In Part IV, after briefly addressing anticipated criticisms of the proposal, I review its possible applications at various points in the Court's history. This historical exercise provides strong support for the adoption of the proposal and reinforces an important point of this Comment: that any interference with the appointment process must be implemented under circumstances that carefully preserve the Court's independence.

number of writers have commented on the potential long-term effects of President Reagan's numerous appointments to the federal bench. See, e.g., Goldman, Reaganizing the Judiciary: The First Term Appointments, 68 Judicature 313, 314 (1985); Podesta, Courtpacking-Reagan Style, L.A. Daily J., Aug. 1, 1985, at 4, col. 3 (quoting Professor Herman Schwartz's observation that many of the Reagan administration's appointees have been "unusually young" and "committed to extreme conservatism"). With the increasingly lower proportion of federal cases reviewed by the Supreme Court, the composition of the appellate courts has taken on even greater significance. See Stewart, Judicial Mavericks, Wall St. J., Dec. 19, 1984, at 1, col. 1 (describing the ideological clash between the Supreme Court and the Court of Appeals for the Ninth Gircuit and noting that "[i]n most . . . cases, the Ninth Gircuit has the last word. . . . Only a tiny fraction of its opinions can be reviewed by the Supreme Court."); Glekel, No Need for a New Court, Nat'l L.J., May 30, 1983, at 13, col. 1 ("[T] he growing number of appellate decisions . . . may be creating a situation where courts with increasing frequency ignore or circumvent Supreme Court precedents with the expectation that constraints upon the size of its docket make the prospect of Supreme Court review extremely remote."); of. Dronenburg v. Zech, 746 F.2d 1579, 1583 (D.C. Cir. 1984) (Bork, J., statement in support of per curiam order) ("[C]ourts are not required to approve uncritically any idea advanced by a constitutionally superior court. Lower court judges owe the Supreme Court obedience, not unquestioning approval."). 


\section{The Court-Packing Problem}

\section{A. Historical Foundations}

In its narrowest sense, "court packing" refers to changing the size or structure of the Court to permit the appointment of additional Justices. ${ }^{18}$ Frequently, however, the term has been used more expansively to refer to any instance in which political considerations influence the appointment process. One commentator went so far as to assert that "every time a President nominates a person to the Bench and the nomination is confirmed by the Senate, the President indulges in 'court packing." "17 Such an expansive definition confuses the legitimate role of executive and legislative discretion in the appointment process with an actual manipulation of that process to achieve temporary political gain. A more narrow definition-encompassing increases or decreases in the Court's size that change the normal frequency of appointments-provides a better focus on the issues discussed in this Comment.

Conversations about court packing often begin and end with a discussion of events occurring during the Roosevelt and Grant administrations. Even when court packing is defined simply in terms of a change in the Court's size, however, the nation's history includes several other important attempts to pack the Court.

In theory, nonpartisan political considerations might explain the early increases in the Court's size from its original membership of six Justices. In the early years of the republic, the number of positions on the Supreme Court corresponded to the number of judicial circuits. The expansion of the nation's population and territory eventually required an increase in the number of circuit courts and correspondingly in the number of positions on the Court. For example, in 1837, the size of the Court was increased from six to eight members as two new circuits were created in the western and southwestern regions of the country. ${ }^{18}$

${ }^{16}$ See, e.g., J. Ely, Democracy and Distrust 46 (1980) (referring to court packing as "[a]ltering the size of ... the Court").

17 Saylor, supra note 14, at 147; see also Peck, supra note 14, at 13 (apparently applying a similarly broad definition); Pike, The Court-Packing Plans, Nat'l L.J., Aug. 29, 1983, at 1, col. 1 (using the term to describe appointments to the federal bench during the administrations of Presidents Carter and Reagan); $c f .$, e.g., Fein, $A$ Proper Check on the Supreme Court, A.B.A. J., Aug. 1985, at 36, 36-37 (using the term to refer to the appointment of judges with philosophical views compatible with those of the President); Schwartz, The Senate Can Play Too, A.B.A. J., Aug. 1985, at 36, 36 (same). Many of the discussions surrounding the 1984 presidential campaign referred to the upcoming opportunity to "pack" the Court with new appointees. See, e.g., Kaplan, supra note 1, at 6, col. 1 (stating that "[w]hoever captures the White House . . . has a real chance to appoint a working majority to the high Court").

${ }^{18}$ See Act of Mar. 3, 1837, ch. 34, 5 Stat. 176, cited in 2 C. WARREN, ThE 
In practice, however, these changes in the size of the Court were not immune from political manipulation. The 1837 proposal was stalled until the last day of President Jackson's term in office because of Congress's unwillingness to allow Jackson to make any new appointments. ${ }^{10}$ Other changes and proposed changes-such as a Senate attempt to eliminate the position to which Jackson was expected to appoint Roger Brooke Taney-reveal even more clearly the political motivations underlying interference with the normal sequence of appointments. ${ }^{20}$

The two most important instances of court packing occurred during critical stages in the nation's history: Reconstruction and the New Deal. The first of these episodes began during the administration of Andrew Johnson. Johnson's term in office was marked by extraordinary conflict among the branches of government. The President's battle with the radical Reconstructionists in Congress, which raged throughout his term, eventually led to Johnson's trial for impeachment. ${ }^{21}$ Congress's relations with the Court were similarly strained. Upset by the Court's decision in Ex parte Milligan, ${ }^{22}$ and anticipating an adverse decision in Ex parte McCardle ${ }^{23}$ Congress enacted the Habeas Corpus Act of $1868,{ }^{24}$ which stripped the Court of its appellate jurisdiction over the issues presented in McCardle. ${ }^{25}$

SuPreme Court in UnIted States History 39 (1932). An increase in membership also may have been required to enhance the perception of the Court's legitimacy. With only six or seven members, appointment opportunities arose less frequently, and the populace had fewer opportunities to affect the makeup of the Court. Presidents Jefferson, Madison, Monroe, and John Quincy Adams appointed a total of only seven Justices during their combined total of 28 years in office: an average of 1.0 appointments per four-year term. See G. GuNTHER, supra note 8, at app. A. In contrast, since 1869, when the Court's nine-member size was firmly established, see Act of Apr. 10, 1869, ch. $22, \S 1,16$ Stat. 44,44 (current version at 28 U.S.C. $\S 1$ (1982)), appointments have occurred at an average rate of 2.3 appointments per four-year term. See G. GuNTHER, supra note 8 , at app. A.

10 See 2 C. WARREN, supra note 18 , at 39.

20 See Abraham, "A Bench Happily Filled:" Some Historical Reflections on the Supreme Court Appointment Process, 66 Judicature 282, 291 (1983).

${ }^{21}$ For an account of the Johnson impeachment proceedings, see generally $\mathrm{D}$. DEWITT, IMPEACHMENT AND TRIAL OF ANDREW JohNSON (1903). Johnson was acquitted in May 1868. See 2 C. WARREN, supra note 18, at 485.

2271 U.S. (4 Wall.) 2 (1866) (holding that during the Givil War the President lacked the power to conduct trial by military tribunal in localities in which the civil courts were open), discussed in 2 C. WARREN, supra note 18, at 423-49.

${ }^{23} 74$ U.S. ( 7 Wall.) 506 (1869), discussed in 2 C. WARREN, supra note 18, at $465,472-88$.

24 Act of Mar. 27, 1868, ch. 34, 15 Stat. 44 (repealing part of the Act of Feb. 5, 1867, ch. 28, 14 Stat. 385).

${ }_{28}$ See 2 C. WARREN, supra note 18 , at $474-88$. Writing for a unanimous Court, Chief Justice Chase found that the 1868 Act had indeed deprived the Court of its jurisdiction: "[J]udicial duty is not less fitly performed by declining ungranted jurisdic- 
Out of this conflict arose an extraordinary court-packing incident. At the time Johnson took office, the Court consisted of ten members; a tenth circuit and a seat on the Court had been added in $1863 .{ }^{28}$ Justice John Catron died during Johnson's first year in office, and Johnson nominated Henry Stanbery to succeed him. ${ }^{27}$ Rather than confirming or rejecting the nomination, Congress enacted legislation that eliminated the position vacated by Catron and called for the eventual reduction of the number of Associate Justices to seven. ${ }^{28}$ The Court was reduced to eight members in 1867, following the death of Justice James Wayne. ${ }^{29}$

When Republican Ulysses Grant took office, Congress increased the Court's size to nine members. ${ }^{30}$ With this new position, in addition to a vacancy created by the resignation of Justice Robert Grier, Grant was poised to effect a substantial change in the composition of the Court.

Grant had good reason to consider his choices carefully. The Court had recently heard argument in Hepburn v. Griswold, ${ }^{31}$ which concerned the validity of Civil War legislation authorizing the use of Treasury notes as legal tender. ${ }^{32}$ Grant eventually appointed William Strong and Joseph P. Bradley to fill the vacancies on the Court. On the same day that Grant sent these names to the Senate, the Court announced its decision to prohibit the retroactive application of the legal tender acts. ${ }^{33}$ In reaching its decision, the Court used reasoning sufficiently broad to invalidate even prospective enforcement of the legislation. ${ }^{34}$ Little more than a year later, however -with both new Justices joining the Hepburn dissenters-the Court reversed that decision and sustained the legal tender acts "in the broadest possible manner."

tion than in exercising firmly that which the Constitution and the laws confer." $M c$ Cardle, 74 U.S. (7 Wall.) at 515, quoted in 2 C. WARREN, supra note 18, at 488.

26 See Act of Mar. 3, 1863, ch. 81, 12 Stat. 755.

27 See 2 C. WARREN, supra note 18 , at 422.

28 See id. at $422-23$ (referring to the Act of July 23, 1866, ch. 210, 14 Stat. 209).

29 See id.

so See Act of Apr. 10, 1869, ch. 22, § 1, 16 Stat. 44, 44 (current version at 28 U.S.C. § 1 (1982)). (1871).

s1 75 U.S. (8 Wall.) 603 (1870), rev'd, Knox v. Lee, 79 U.S. 457 (12 Wall.) 457

${ }^{32}$ See id. at 612-26 (discussing Act of Feb. 25, 1862, ch. 33, 12 Stat. 345); see also 2 C. WARREN, supra note 18, at 498-527 (discussing the legal tender cases). The debate over the constitutionality of the legal tender legislation pitted banks, which demanded payment in gold, against their debtors, who sought to pay gold-based, pre-Civil War debts with depreciated paper currency. See id. at 498-99.

ss See 2 C. WARREN, supra note 18, at 516 (discussing Hepburn, 75 U.S. (8 Wall.) at 625-26).

st See id. at 511-13.

ss Id. at 522-25 (citing Knox v. Lee, 79 U.S. (12 Wall.) 457 (1871)). 
Charles Warren has argued persuasively that Grant did not "pack" the Court in the sense of using the two appointment opportunities specifically to overrule Hepburn. Apparently Grant had no advance knowledge of the decision, and in any event he could have chosen nominees more certain to overrule the case if that had been his sole purpose. ${ }^{36}$ Nevertheless, the entire sequence of events, including the congressional manipulation of the Court during the Grant administration, undoubtedly did much harm to the public's perception of the Court's independence and legitimacy. ${ }^{37}$

The second major court-packing incident, the Roosevelt plan of 1937 , is a more recent and familiar example. Roosevelt entered his second term in office on the strength of a landslide victory over Governor Alf Landon and with the resolve to address two related frustrations of his first term in office. First, he had not yet made any appointments to the Court. ${ }^{38}$ Second, the Court had more than once struck down his New Deal legislation. ${ }^{39}$ Led by four Justices appointed prior to 1923-McReynolds, Van Devanter, Sutherland, and Butler-who were joined frequently by Justice Roberts, a Hoover appointee, the Court found that Roosevelt's innovative proposals exceeded the authority granted under the commerce clause and other constitutional provisions. $^{40}$

Roosevelt's court-packing plan called for the appointment of an additional Justice for each Justice over the age of seventy. ${ }^{41}$ Proposed ostensibly as a method of easing the burdens on an overworked Court, the plan was immediately recognized and criticized as a plan to fill the

se See id. at 517-18. But cf. L. TRIBE, supra note 1, at 62 (Although "Grant had decided to nominate Strong and Bradley before the Hepburn decision was announced .. . there is no doubt that Grant knew that a ruling in the case was on the way, and that the issue of paper currency was of great importance to his administration.").

${ }^{37} C f .2$ C. WARREN, supra note 18, at 522 (Reopening the legal tender cases "has been regarded as a very grave mistake-and a mistake which for many years impaired the people's confidence, not in the honesty, but in the impartiality and good sense of the Court."). As one Ninth Circuit judge noted in a recent case, the strength of the judicial system requires "not only the reality but also the appearance of judicial independence." United States v. Woodley, 751 F.2d 1008, 1022 (9th Gir. 1985) (en banc) (Norris, $J$., dissenting).

${ }^{38}$ Roosevelt's first appointee to the Court, Justice Hugo Black, was appointed in 1937. See G. GunTHER, supra note 8, at app. A.

s9 See, e.g., Louisville Joint Stock Land Bank v. Radford, 295 U.S. 555 (1935) (striking down the Frazier-Lemke Act, ch. 869, 48 Stat. 1289 (1934)); Schechter Poultry Corp. v. United States, 295 U.S. 495 (1935) (striking down the National Industrial Recovery Act, ch. 90, 48 Stat. 195 (1933)); see also L. Pfeffer, This Honorable Court 295-311 (1965) (describing a number of adverse decisions announced during Roosevelt's first term).

to See id. at 293-317.

41 See id. at 314. 
Court with Justices sympathetic to the New Deal program. ${ }^{42}$ Congress never acted on the proposal.

A number of commentators have suggested that the court-packing plan, although never enacted, may have pressured the Court into its subsequent approval of New Deal legislation. ${ }^{43}$ Others have pointed to recent evidence indicating that the Court's "switch" in the key case, West Coast Hotel v. Parrish, ${ }^{44}$ was actually determined prior to the announcement of the plan. ${ }^{45}$ Whatever the case, the Roosevelt incident has bestowed a legacy of distrust on any proposal to interfere with the appointment process. ${ }^{46}$ This legacy has reinforced a natural tendency to avoid changes in the Court's traditional size and system of appointments.

\section{B. The Role of Tradition}

The tradition of a nine-member Court has been established by nearly a century of unvarying practice. Although the size of the Court is set by statute ${ }^{47}$ and presumably may be modified by the normal legislative process, ${ }^{48}$ some care should be exercised in assessing any proposal to change a governmental tradition of such long standing. Indeed, in view of the checkered history of past legislative efforts, many observers

12 See id. at 314-16.

ts See, e.g., H. Abraham, Justices and Presidents 196-99 (1974) ("No matter how insistently [Justices] Hughes and Roberts might later deny that their switch to the liberal wing had been politically motivated, few students of the Court view their move as anything but a recognition of the handwriting on the wall.'); see also L. PFeFFER, supra note 39, at 316-17 (stating that the remark that Roosevelt " "lost the battle but won the war" " has "become almost a cliche in legal circles"); cf. W. Leuchtendurg, Frankin D. Roosevelt and the New Deal 1932-1940, at 23839 (1963), cited in Feinberg, supra note 14, at 265 n.95 (suggesting that the courtpacking plan destroyed the unity of the Democratic majority in Congress, impeded the enactment of subsequent New Deal legislation, and thus ultimately failed); Choper, The Supreme Court and the Political Branches: Democratic Theory and Practice, 122 U. PA. L. REv. 810, 852 (1974) (referring to the "widely acknowledged fact that [Roosevelt's] legislative mastery suffered greatly as a result").

14300 U.S. 379 (1937).

45 See, e.g., J. EIY, supra note 16, at 46 ("[R]ecently discovered Court records have indicated ... . that the Court's 'switch' was independent of (in fact prior to) the announcement of [Roosevelt's] plan.").

${ }_{16}$ Jesse Choper, for example, in reflecting on the aftermath of the court-packing incident, asserted that "the political departments' power over the Court's composition, far from being seriously considered a consequential weapon, has been effectively discredited." Choper, supra note 43 , at 852 .

17 See 28 U.S.C. $\S 1$ (1982) ("The Supreme Court . . . shall consist of a Chief Justice . . . and eight associate justices ....".).

48 Compare McKay, supra note 8, at 115 (The size of the Court "may be altered at the pleasure of Congress.") with Pugh, The Unconstitutional Aspect of the Proposal to Enlarge the Supreme Court, 22 MAss. L.Q. 24, 28-29 (1937) (arguing that the 1937 plan would have been unconstitutional). 
would reject without question the wisdom, if not the constitutionality, of changing in any way the current method of determining the Court's membership. ${ }^{49}$

Although these are compelling concerns, there are equally compelling arguments for rejecting practices that do not adequately serve the constitutional values that guided their formation. The form of this debate is suggested by a recent case from the Ninth Circuit, United States v. Woodley. ${ }^{\text {so }}$

Woodley involved a related, but clearly distinguishable, issue concerning appointments to the federal bench. The appellant in Woodley was a criminal defendant whose case had been heard by a recently appointed federal judge, Walter M. Heen. Judge Heen had been nominated by President Garter in February 1980. The Senate recessed at the end of that year without taking a vote on Heen's confirmation. On December 31, 1980, President Garter conferred a commission on Judge Heen pursuant to the recess appointments clause of the Constitution. ${ }^{51}$ Subsequently, on January 21, 1981, President Reagan withdrew Heen's nomination. Acting on the authority of his commission, however, Heen continued to serve on the bench until the conclusion of the first session of the ninety-seventh Congress. During this period, Heen denied Woodley's suppression motion and presided over a bench trial at which Woodley was convicted on three counts of narcotics violations. ${ }^{52}$

On appeal, Woodley challenged the denial of her suppression 'motion. A panel of the Ninth Circuit vacated her conviction based on its finding that Judge Heen did not have the constitutional authority to preside over her trial. ${ }^{53}$ The Ninth Circuit, sitting en banc, reversed the panel's decision. ${ }^{54}$

The key issue in the case arose because of a direct conflict between two constitutional provisions governing federal appointments. On the one hand, article III provides that judges "shall hold their Offices during good Behaviour." On the other hand, the recess appointments clause, in equally unambiguous language, empowers the President "to

49 See, e.g., Choper, supra note 43, at 855 ("[T]he constitutional legitimacy of [changes in the Court's composition] against the Court's rule is greatly suspect; most may be seen as anticonstitutional in tradition, if not unconstitutional in law.").

so 751 F.2d 1008 (9th Cir. 1985) (en banc).

81 See id. at 1009 (referring to the recess appointments clause, U.S. CoNsT. art. II, § 2, cl. 3).

${ }_{52}$ See id.

ss See United States v. Woodley, 726 F.2d 1328 (9th Gir. 1984), rev'd en banc, 751 F.2d 1008 (9th Cir. 1985).

s4 See Woodley, 751 F.2d at 1014 (holding that "a recess appointee to the federal bench . . . could exercise the judicial power of the United States").

ss U.S. ConST. art. III, § 1. 
fill up all Vacancies that may happen during the Recess of the Senate, by granting Commissions which shall expire at the End of their next Session."

In denying Woodley's appeal, the Ninth Circuit acknowledged that the article III appointments clause, by its terms at least, allows no exception to the rule that judges appointed pursuant to that clause should be afforded life tenure. ${ }^{87}$ At the same time, however, the court noted that on numerous occasions in the nation's history, including the first presidential administration, the recess appointments clause had been invoked for the appointment of article III judges:

The United States Supreme Court has made clear that considerable weight is to be given to an unbroken practice, which has prevailed since the inception of our nation and was acquiesced in by the Framers of the Constitution when they were participating in public affairs. . . . Much in the same way, the use of the recess provision to appoint federal judges has been inextricably woven into the fabric of our nation. ${ }^{58}$

Based in large part on the weight of this tradition, the court concluded that the recess appointee should be "view[ed] . . . not as a danger to the independence of the judiciary, but as the extraordinary exception to the prescriptions of article III."'59

Judge Norris, joined in dissent by three other judges of the Ninth Circuit, agreed with the majority's characterization of the text of the two provisions but sharply criticized other aspects of the court's analysis:

[T] he majority skips what I believe should be a crucial step in the constitutional inquiry: evaluating and balancing the competing constitutional values at stake. Because of its uncritical acceptance of the historical practice as determinative of the constitutional issue, the majority fails to make any serious comparative analysis of the concerns for governmental efficiency underlying the Recess Appointments Clause and the principle of judicial independence underlying the tenure and salary provisions of Article III. ${ }^{60}$

\footnotetext{
se Id. art. II, $\S 2$, cl. 3 .

${ }^{87}$ See Woodley, 751 F.2d at 1010.

s8 Id. at 1012 (citations omitted).

so Id. at 1014 (citations omitted).

oo Id. at 1015 (Norris, J., dissenting).
} 
Judge Norris found that the concerns for governmental efficiency were relatively slight and could be accommodated by methods commonly used elsewhere in the federal judicial system: the government could make interdistrict assignments or other temporary adjustments until a properly confirmed judge could be seated on a more permanent basis. ${ }^{61}$ At the same time, Judge Norris found that the majority's interpretation was substantially inconsistent with the concept of an independent judiciary. During the period preceding confirmation or withdrawal of the nomination, recess appointees would review cases with unavoidable attention to the political branches' power to end their tenure. ${ }^{62}$ In the absence of an unambiguous text or significant historical evidence of the framers' intent, these concerns were sufficient to persuade the dissenters that recess appointments of article III judges should be declared unconstitutional. ${ }^{63}$

The actual holding of Woodley does not affect this Comment's inquiry into court packing. Changing the size of the Court, unlike prohibiting the use of recess appointments, does not run afoul of a specific constitutional provision or a historical practice extending back to the nation's first administration. To the contrary, statutory adjustments in the Court's size were relatively common throughout the nation's first century.

The two opinions in Woodley do, however, teach a critical lesson about constitutional analysis at the fundamental level represented by appointments to the Court: that, although historical practice should be given considerable weight in assessing matters of constitutional dimension, such practice should not be dispositive in instances in which it undermines essential constitutional values. Defending the current appointment system by asserting that "things have worked pretty well the way they are" is both misleading and inadequate: misleading because we have no way of knowing whether past maldistribution of appointment opportunities has undermined important constitutional values, and inadequate because decisions of this importance must reflect the possibility of unforeseen developments. With respect to the latter point, Judge Norris noted the possibility that a constitutional confrontation such as Youngstown Sheet $\&$ Tube Co. v. Sawyer ${ }^{64}$ or United States $v$. Nixon $^{65}$ could be decided by the vote of a recess appointee. ${ }^{68}$ In such a

1 See id. at 1024.

62 See id. at 1022-23.

6s See id. at 1032-33.

o4 343 U.S. 579, 587-89 (1952) (holding that President Truman lacked constitutional authority for unilateral seizure of the steel mills).

os 418 U.S. 683, 713-16 (1974) (ordering President Nixon to release the Watergate tapes). 
case, the mere appearance of political pressure, even with respect to judges fully capable of ignoring all undue political influences, could destroy the integrity of the judicial process. ${ }^{67}$

As suggested in Part IV of this Comment, there have already been a number of instances in which the Court's actual or perceived ability to act independently may have been undermined by the random timing of appointments. Moreover, the nation has recently entered an unusual period in its history: one President has served a full term and left office without making a single appointment to the Court, and his successor might appoint several new Justices over the course of the next few years. Whether or not these appointments actually take place, the strong possibility of future threats to the Court's independence, as well as the absence of a persuasive justification for randomly allocated appointments, is more than sufficient reason to undertake an inquiry of the sort suggested by Judge Norris.

\section{Analysis of the Gurrent System}

An appointment system should be evaluated based on its capacity to generate a Court having the following partially interdependent characteristics: independence, legitimacy, and competence.

\section{A. Independence}

Throughout the history of the Court, commentators have stressed the importance of judicial "independence." meaning of the term and the reasons for its importance have been somewhat elusive.

Understanding judicial independence begins with an analysis of separation-of-powers doctrine. There are at least three distinct types of separation represented in the divisions of government: separation of functions, separation of agencies, and separation of persons. ${ }^{68}$ To some extent the division of responsibility reflects the suitability of particular branches for performing certain functions. The legislature, for example, with its diverse and representative membership, deliberative processes, and decisions based on majority vote, may be particularly well suited

68 See Woodley, 751 F.2d at 1022-23 (Norris, J., dissenting).

67 See id.

os Recent examples include Feinberg, supra note 14, at 268-76 (criticizing legislative attacks on judicial independence); Kaufman, The Essence of Judicial Independence, 80 Colum. L. REv. 671, 672 (1980) (applying an "analytic framework . . to illustrate the critical importance of a fully independent judiciary").

69 See M. Vile, Constitutionalism and the Separation of Powers 14-17 (1967). 
for the enactment of legislation. The division of government into separate agencies theoretically protects against the exercise of tyrannical and self-interested leadership. In the area of criminal law, for example, the fact that different agencies are responsible for enactment, prosecution, and adjudication tends to reduce unfairly selective enforcement. When enacting a particular law, the legislature cannot be certain that the law will not be enforced against its members and their friends or constituents. Finally, for related reasons, there is some value in specifying that different individuals be charged with fulfilling the various responsibilities of government. ${ }^{70}$ The involvement of different persons makes collusion more difficult and helps to enforce the separation of functions and agencies.

Integrated with this basic theory is the system of checks and balances. ${ }^{71}$ Presidents may veto legislation, ${ }^{72}$ Congress may impeach Presidents and judges ${ }^{73}$ and override presidential vetoes, ${ }^{74}$ and judges may strike down legislation that they determine to be unconstitutional. ${ }^{75}$

The effective maintenance of this form of government depends on the continued independence of the three branches. Maintaining an independent judiciary, however, poses a unique set of problems. Without the power of purse or sword, and without a natural political constituency, the "least dangerous branch"76 is especially susceptible to manipulation by the political branches. ${ }^{77}$

Moreover, the special role of the judiciary, and the Supreme Court in particular, makes its independent character exceptionally important. In performing its tasks, the Court must be independent not only from the other branches but also from the pressures of popular opinion. Alexander Hamilton referred to the need to resist those "ill humors . . . which, though they speedily give place to better information, and more

70 The "separation of persons" concept receives specific recognition in the Constitution. See U.S. CoNST. art. I, $\S 6$, cl. 2 ("[N]o Person holding any Office under the United States, shall be a Member of either House during his Continuance in Office.").

71 See M. VILE, supra note 69, at 18-19.

72 U.S. CONST. art. I, $\S 7$, cl. 2.

${ }^{73}$ Id. $\S 2$, cl. $5, \S 3$, cls. 6-7; cf. id. art. III, $\S 1$ ("The Judges . . . shall hold their Offices during good Behaviour .....").

74 Id. art. I, \& 7, cl. 2.

75 See Marbury v. Madison, 5 U.S. (1 Cranch) 137 (1803).

${ }^{76}$ The Federalist No. 78, at 465 (A. Hamilton) (G. Rossiter ed. 1961) ("[T] he judiciary . . . will always be the least dangerous to the political rights of the Constitution; because it will be least in a capacity to annoy or injure them."); see also Kaufman, What Did the Founding Fathers Intend?, N.Y. Times, Feb. 23, 1986, $§ 6$ (Magazine), at 42,69 ("Lacking the power of the purse or the sword, the courts must rely on the elected branches to enforce their decisions.").

"77 For a discussion of these issues in connection with the Court's consideration of presidential immunity, see Carter, The Political Aspects of Judicial Power: Some Notes on the Presidential Immunity Decision, 131 U. PA. L. REV. 1341 (1983). 
deliberate reflection, have a tendency, in the meantime, to occasion dangerous innovations in the government, and serious oppressions of the minor party in the community." ous innovations," the Court serves to mitigate the effects of temporary changes in public opinion. ${ }^{79}$ The Court still might reflect popular consensus within this role, but the community from which that consensus is derived might consist of a generation rather than a two- or four-year majority. ${ }^{80}$ Second, the protection of the "minor party in the community" has been viewed as one of the central foundations for the Court's exercise of judicial review. ${ }^{81}$ The effective fulfillment of this role also requires some degree of insulation from majoritarian influence.

The combination of the Court's relative institutional weakness and the unpopularity of its counter-majoritarian role requires that the institution receive extraordinary protection. The Constitution's structural protections of the judiciary, including life tenure and the prohibition on reductions in salary, ${ }^{82}$ are necessary but insufficient conditions for the Court's survival. The political branches can draw from several sources of institutional power should they seek to threaten the Court and influence its judgment: the powers to impeach, ${ }^{83}$ to restrict the Court's juris-

78 The Federalist No. 78, at 469 (A. Hamilton) (G. Rossiter ed. 1961).

79 Cf. Kaufman, supra note 68 , at 694 (referring to the "risk that constitutional interpretation will succumb to popular pressures" as "a blow to the very substance and existence of judicial power"); id. at $694 \mathrm{n} .141$ (" "Courts are not representative bodies. They are not designed to be a good reflex of a democratic society.' ") (quoting Dennis v. United States, 341 U.S. 494, 525 (1951) (Frankfurter, J., concurring)).

${ }^{80}$ See Rees, supra note 14, at 916 n.7:

There are many variations on the formula by which judicial review is reconciled with the idea of "rule by the people" by reference to some definition of "the people" that includes other people than those who voted in the last election. The classic formulation is that of Edmund Burke, whose governing consensus would have included many generations now dead and perhaps some not yet born ....

See also id. at 917 n.8 (" "The people, as Burke used the term, was a body in place, gathered, led, manifesting its temper in many ways over a span of time as a whole . . . not speaking merely on occasion in momentary numerical majorities." ") (quoting A. Bickel, The Morality of Consent 17-18 (1975)).

${ }_{81}$ Cf. United States v. Carolene Prods. Co., 304 U.S. 144, 152 n.4 (1938) (referring to the possibility that "prejudice against discrete and insular minorities may be a special condition, which tends seriously to curtail the operation of those political processes ordinarily to be relied upon to protect minorities, and which may call for a correspondingly more searching judicial inquiry") (citations omitted), discussed in $\mathrm{J}$. ELY, supra note 16 , at 75-77.

${ }_{82}$ U.S. ConsT. art. III, § 1.

8s The impeachment clause is generally regarded as the only mechanism for the removal of a federal judge appointed pursuant to article III. Compare Kaufman, supra note 68, at 697-98 \& $698 \mathrm{n} .162$ (Impeachment is the only mechanism for removal of federal judges.) with Berger, Impeachment of Judges and "Good Behavior" Tenure, 79 YALE L.J. 1475 (1970) (arguing that removal may be appropriate for "bad behavior" less objectionable than that required for impeachment). In view of its infrequent 
diction, ${ }^{84}$ to reduce the Court's operating budget, ${ }^{85}$ to pass constitutional amendments overruling the Court's decisions, ${ }^{86}$ and, admittedly, to pack the Court. ${ }^{87}$ Obviously, there are serious impediments to the

use, however, it is unlikely to represent a substantial restraint on the Court's power. See, e.g., J. Ely, supra note 16, at 46 ("II]mpeachment might have developed into an effective mode of controlling decision. However, ... . it didn't, and today it is understood to be a weapon reserved for the grossest of cases."). Only one Supreme Court Justice has ever been subjected to formal impeachment proceedings, and he was acquitted. See McKay, supra note 8, at 114 (referring to the 1804 acquittal of Justice Chase).

84 Under article III of the Constitution, the "original" jurisdiction of the Court is limited to cases "affecting Ambassadors, other public Ministers and Consuls, and those in which a State shall be a Party." U.S. ConsT. art. III, § 2, cl. 2. Within the remaining cases subject to the judicial power of the United States, the Court has "appellate" jurisdiction, "with such Exceptions, and under such Regulations as the Congress shall make." Id.

In 1868 the Congress, acting in anticipation of the Court's decision in Ex parte McCardle, 74 U.S. (7 Wall.) 506 (1868), passed legislation stripping the Court of its appellate jurisdiction under the Habeas Corpus Act of 1867. See supra text accompanying notes 22-25. More recently, there have been a number of unsuccessful attempts to strip the Court of jurisdiction over various types of cases. See, e.g., Elliot, CourtCurbing Proposals in Congress, 33 Notre Dame Law. 597, 600-06 (1958) (describing numerous court-stripping measures proposed between 1937 and 1958); Feinberg, supra note 14, at 270-73 (describing the "Judicial Reform Act of 1982," which proposed, among other changes, the repeal of 28 U.S.C. $\$ 1331$ (1982) (conferring federal question jurisdiction)). Numerous scholars have raised serious questions about the constitutionality of these proposals. See, e.g., J. ELY, supra note 16, at 46 ("Congress's theoretical power to withdraw the Court's jurisdiction over certain classes of cases is ... fraught with constitutional doubt ....") (footnote omitted); Clinton, A Mandatory View of Federal Court Jurisdiction: A Guided Quest for the Original Understanding of Article III, 132 U. PA. L. REv. 741, 854 (1984) ("[T]he framers did not leave the appellate jurisdiction of the Supreme Court to congressional whim ....".).

${ }_{85}$ Commentators have generally discounted the effectiveness of budgetary control. See, e.g., J. EIY, supra note 16, at 46 (Control over the budget "has proved an instrument too blunt to be of any real control potential."); Carter, supra note 77, at 1380 n.157 (noting that the Justices "can continue to issue their opinions, even if they must scribble them on cardboard found in the street"); Choper, supra note 43, at 849 (Congressional control over the Court's budget is "[o]f minor significance . . . because [it is] used more in pique than with seriousness of purpose."). Congress, of course, may not reduce funds constituting "compensation" to the Justices. See U.S. CoNST. art. III, § 1.

86 See U.S. ConsT. art. V; see also Feinberg, supra note 14, at 255, 261, 263 \& $\mathrm{n} .85$ (describing four instances in which a constitutional amendment has effectively overruled a decision of the Court). More recent proposals include a constitutional amendment, which, if enacted, would effectively overrule the Court's decision in Roe v. Wade, 410 U.S. 113 (1973). See Legal Ramifications of the Human Life Amendment: Hearings Before the Subcomm. on the Constitution of the Senate Comm. on the Judiciary, 98th Cong., 1st Sess. (1983); Rice, Overruling Roe v. Wade: An Analysis of the Proposed Constitutional Amendments, 15 B.C. InDUs. \& CoM. L. REv. 307 (1973). Senator Orrin Hatch stated that "[m]ost members [of the Senate] voting to overturn Roe were clearly voting to restore what they believed to have been the status [quo]. They were not voting to change the Constitution in their view . . . but to restore a changed Constitution." Speech of Senator Orrin Hatch, Second Annual Federal Circuit Judicial Conference, 104 F.R.D. 207, 235 (1984).

${ }^{87}$ See supra text accompanying notes 21-46 (describing court-packing incidents in 
exercise of each of these powers, although the mere threat of their use may be sufficient to instill some level of temerity. ${ }^{88}$ More substantial than any of these threats to judicial independence, however, is the imperative that the Court rely on others for the enforcement of, and adherence to, its judgments. ${ }^{88}$

\section{B. Legitimacy}

The critical addition to the Court's structural protections, the support that allows the Court to maintain such an apparently untenable position, is the broadly held perception of its legitimacy. The rationale for the Court's legitimacy departs substantially from the arguments used to justify the actions of the political branches. A representative statement of this distinction was set forth in a recent article by Owen Fiss:

The legislative and executive branches derive their legitimacy from their responsiveness to popular will . . . . With the judiciary, however, ... . [t] the foundation of . . . power is process. Judges are entrusted with power because of their special competence to interpret public values embodied in authoritative texts, and this competence is derived from the process that has long characterized the judiciary and that limits the exercise of its power. . . . We accept the judicial power on these terms .... ${ }^{90}$

Other commentators, many of whom focus on the special problem of the legitimacy of judicial review, likewise look beyond the electoral process to justify the Court's actions. Some have emphasized the Court's role in preserving the rights of individuals, ${ }^{91}$ while others, most prominently John Ely, have stressed the Court's role in reinforcing the representative process through which the political branches make public policy. ${ }^{92}$

the Andrew Johnson, Grant, and Franklin Roosevelt administrations).

${ }^{88} \mathrm{Cf}$. Choper, supra note 43 , at 854 (The threat of legislative action may have "had some immeasurable impact on the Court's judgments.") (citing W. MURPHY, Congress aNd THE Court 245-46 (1962)).

${ }^{80}$ See Carter, supra note 77, at 1380 ("The major check . . . is the most practical one, self-imposed to avoid an external threat: the realization that other branches of the federal government may refuse to comply with the courts' dictates."); see also Choper, supra note 43, at 855-56 (noting, among other examples, President Eisenhower's "seeming ambivalence" immediately following the issuance of Brown v. Board of Educ., 347 U.S. 483 (1954)).

${ }^{90}$ Fiss, The Bureaucratization of the Judiciary, 92 YALE L.J. 1442, 1443 (1983).

91 See M. PERry, supra note 15.

92 See J. ELY, supra note 16. 
Emphasizing nonpolitical sources of the Court's legitimacy makes perfect sense: the core of the Court's value lies in its nonpartisan foundations. In view of the central role that the electoral process plays in democratic theory generally, ${ }^{93}$ however, one suspects that students of the Court may have placed too little emphasis on the Court's link to the electoral process-the representative appointment of its members. Most commentators recognize this link but place far too little weight on it in discussing the legitimacy of the Court. ${ }^{84}$

The importance of this connection might be illustrated best by contrasting the current system with two possible alternatives. In the first, the Justices themselves would make the appointments necessary to fill any vacancies on the Court. Such a system, used extensively in nonjudicial settings, ${ }^{96}$ seems perfectly capable of supporting the Court's nonpolitical character. In addition, the seated Justices may be particularly well qualified to select men and women of appropriate judicial temperament, integrity, and skill. Yet there is a sense in which this system seems lacking. Perhaps we are unwilling to lose all control over the selection of the men and women who so significantly affect our lives, even while we recognize the value of creating an institution that, once constituted, will be effectively insulated from political influence. ${ }^{86}$

In the second method, Justices would be selected only during the administrations of a designated political party. Allowing, for example, only Democrats to select Justices clearly would have none of the virtues of the method described above and would present a host of practical problems as well. Nevertheless, reaction to this proposal may illustrate the increasing theoretical acceptance ${ }^{97}$ of what has long been accepted

9s See id. at 4 (" "[N]othing can finally depreciate the central function that is assigned in democratic theory and practice to the electoral process . . . " ") (quoting A. Bickel, The Least Dangerous Branch 19 (1962)).

*4 See, e.g., J. ELY, supra note 16, at 47 (acknowledging that "certainly there is something there" in the appointment and confirmation processes yet asserting the need to look elsewhere to establish the legitimacy of the Court). But $c$. Rees, supra note 14, at 913 (finding the notion that "the people select the people who select the judges" important in establishing the compatibility of judicial review with "the idea of government by consent").

95 Examples within the author's experience include a law firm in which the management committee selects new members from among the firm's partners as vacancies arise and a law review in which each year's board of officers selects the board of officers for the following year.

${ }^{\circ}$ Cf. L. TRIBE, supra note 1, at 128-29 (describing instances in which members of the Court have in fact influenced the choice of new Justices and, in particular, characterizing the role of Chief Justice Taft in selecting new Justices as a "story illustrat[ing], as no hypothetical tale could, the perils of allowing the brethren to make of the Supreme Court a self-perpetuating aristocracy").

${ }^{97}$ See Rees, supra note 14 , at 923 \& n.38 (collecting authorities). 
in practice: ${ }^{98}$ that, given a threshold showing of outstanding merit, the President and the Senate ${ }^{99}$ should be able to consider the likely philosophical or jurisprudential leanings of prospective Justices in making their decisions within the appointment process. ${ }^{100} \mathrm{~A}$ system based on a completely random connection between the appointive and electoral processes, in theory at least, could allow Democratic administrations to make every appointment, despite alternating success at the polls. But such a system would not adequately provide for the legitimate, if limited, role that politics should play in the formation of the Court.

One possible counterargument-that Presidents are rarely success-

${ }^{98}$ See, e.g., Abraham, supra note 20, at 284 (stating that the strong correlation between party affiliation of Presidents and their appointees to the Court "point[s] to a broad-gauged commitment to a 'representative' philosophy for judicial appointments"); cf. Schwartz, supra note 17, at 36:

To expect a president not to try to pack the Supreme Court with appointees who share his judicial philosophy is like expecting water to run uphill. From George Washington to Ronald Reagan, no president has behaved so unnaturally. And there is nothing wrong with this. The Constitution contemplated that the president would be a partisan political being. Why should he act apolitically when choosing someone with enormous long-term power over his policies and programs?

${ }^{80}$ A number of writers have distinguished between judges and cabinet officers, suggesting that the Senate should exercise considerably more influence in the confirmation of judges. See, e.g., L. TRIBE, supra note 1, at 78 ("Justices help govern the nation ... . long after the Presidents who appointed them have left the White House. Seats on the Court thus cannot be viewed as merely slots in a second Cabinet."); Black, supra note 14, at 660 ("Wisdom and fairness" suggest that the President be allowed to have "pretty much anybody he wants" for the Gabinet, but "[j]ust the reverse, just exactly the reverse, is true of the judiciary. The judges are not the President's people. God forbid!"); Carter, supra note 77, at 1389 n.189 ("The Senate has tended to scrutinize judicial appointments with a bit more care, and for a reason that should be plain: judges, who remain in office long after the Administration has left, are not part of the President's team."); Rees, supra note 14, at 943 (Considerations supporting Senate deference to Cabinet appointments "would not seem to apply to Supreme Court Justices who have life tenure.").

Despite support for an expanded role, the Senate has been relatively passive in recent confirmation decisions. Compare Rees, supra note 14, at 944 \& n.94 (21 nominees rejected during the nineteenth century) with L. TRIBE, supra note 1, at 78 ("[I]n recent times, the myth [of the "spineless Senate"] has drawn unwarranted credibility from the fact that the five Justices from Justice Blackmun in 1970 through Justice O'Connor in 1981 were in fact confirmed by a vote tally of 448 to $27 \ldots$. .) and McKay, supra note 8, at 131 (only one rejection between 1894 and 1960). Although the necessity of Senate confirmation may operate as a "silent" restraint on the President's initial choice of a nominee, see THE FEDERALIST No. 76, at 457 (A. Hamilton) (C. Rossiter ed. 1961), the effectiveness of this restraint presumably depends on the likelihood that in an extreme case the Senate actually would vote to reject the nomination. Cf. Rees, supra note 14, at 940 ("After President Nixon's nominations of Judges Haynsworth and Carswell were rejected, he nominated someone [Justice Harry Blackmun] who he believed would be acceptable to him and also to at least fifty-one Senators.").

100 See L. TRIBE, supra note 1, at 93-105; Abraham, supra note 20, at 287-88; Rees, supra note 14 , at 937-47. 
ful in predicting the voting records of their appointees ${ }^{101}$-is probably inaccurate and is in any event beside the point. ${ }^{102}$ Tales of Presidents who have completely misjudged their appointees are largely anecdotal and may be offset by examples of Presidents who were undoubtedly delighted with their selections. Frequently mentioned examples of the former include President Dwight Eisenhower, who reportedly described his appointment of Chief Justice Earl Warren as "the biggest damnedfool mistake I ever made,"10s and President Theodore Roosevelt, who reportedly said that "I could carve out of a banana a judge with more backbone"104 than Justice Oliver Wendell Holmes, Jr. Within the latter group of Presidents, one may point to Ulysses Grant, whose appointments of Justices Strong and Bradley led to the prompt reversal of the Court's legal tender decision; ${ }^{108}$ Franklin Roosevelt, who achieved remarkable success in appointing Justices willing to uphold the New Deal;"106 and, more recently, Ronald Reagan, who has had a "stellar track record appointing to the federal bench conservatives who stay

101 Presidents make inaccurate projections for a number of different reasons. They may simply make a mistake, either because of insufficient information or because of excessive attention to short-term policy goals. See M. PERRY, supra note 15, at 127 (" It has ... proved hard to predict how someone in another line of work will function as a justice and one sometimes wonders whether the appointee who turns out differently from the way the President who appointed him expected is not the rule rather than the exception.' ") (quoting J. ELY, supra note 16, at 47); Abraham, supra note 20, at 287 (" 'You shoot an arrow into a far-distant future when you appoint a justice and not [even] the man himself can tell you what he will think about some of the problems he will face." ") (quoting Alexander Bickel's statement in Judgment on a Justice, Time, May 23, 1969, at 23, 24); Peck, supra note 14, at 15 (suggesting that Justice Douglas lamented President Franklin Roosevelt's shortsightedness in appointing supporters of the New Deal who later turned out to be relatively unenthusiastic in civil liberties cases). In addition, the typical length of tenure on the Court and the institutional emphasis placed on judicial independence create an environment in which Justices may depart over time from voting patterns that may have been predicted accurately at the time of their appointments. See Greenhouse, supra note 1, at 1, col. 6, 9, col. 4 (describing the views of Justice Rehnquist); cf. Peck, supra note 14 , at 13 (describing a pattern in which Presidents would continue "to appoint non-Federalist justices . . . only to have them vote with [Federalist Chief Justice] Marshall on issue after issue"); Note, The Changing Social Vision of Justice Blackmun, 96 HARv. L. REv. 717 (1983) (discussing changes in Justice Blackmun's opinions during his tenure on the Court).

${ }^{102}$ For an extensive and persuasive attack on the "myth of the surprised President," see L. TRIBE, supra note 1 , at 50-76.

${ }^{108}$ Kaufman, Keeping Politics Out of the Court, N.Y. Times, Dec. 9, 1984, § 6 (Magazine), at 72, 87:

${ }_{104} I d$.

105 See L. Pfefreer, supra note 39, at 184-85; see also supra notes 30-35 and accompanying text.

${ }^{108}$ See Fein, supra note 17, at 40 (Franklin Roosevelt "deftly exploited [his appointment opportunities] to effectuate a virtual revolution in constitutional law necessary to vindicate his New Deal initiatives."). 
conservatives."107

Even if Presidents were largely unsuccessful in choosing politically sympathetic appointees, their decisions would continue to have a profound effect on the nation's view of the Court. Understanding this effect requires attention to two essential points concerning the connection between judicial appointments and legitimacy. First, the appointive aspect of the Court's legitimacy is grounded largely in the simple notion that the individuals on the Court have been selected by the people's representatives. ${ }^{108}$ The predictability of result is secondary. Indeed, Justices are not supposed to behave uniformly in politically predictable ways, and a system that frustrates that hope to some degree is precisely the sort of system that the framers intended to create.

Second, to the extent that the political choices of Presidents and Senators do partially shape the jurisprudential approach of the Court's membership, the important concern is not the consistent voting records of particular Justices, but rather the sense that the Court as a whole does not represent any particular faction or interest. Under a system, such as the current one, in which an erratic frequency of appointments may significantly over- or under-represent certain administrations or political groups among the Court's membership, the danger of a perception of political factionalism or bias becomes pronounced. ${ }^{109}$ The inability of such a Court to fulfill its role may be illustrated most effectively by a focus on those instances in which the Court achieved a consensus that clearly transcended the political origins of its individual members. In the Watergate tapes case and in a number of civil rights cases, the Court struggled to achieve a unanimous opinion ${ }^{110}$ and was

${ }^{107}$ Kaplan, supra note 1, at 6, col. 4 (attributing this assessment to Professor A.E. Dick Howard of the University of Virginia School of Law).

108 See Rees, supra note 14, at 913 ("One staple ingredient in attempted resolutions of the 'countermajoritarian difficulty' has been the observation that the people select the people who select the judges.") (footnotes omitted).

109 Such perceptions may be particularly significant during periods of intense political controversy. Following the death of Justice Daniel in 1860, as both the nation and the Court were beginning one of their most troubled decades, the New York Courier characterized the Supreme Court Justices in the following terms: "A decided majority of them are the appointees of the party that five sixths of the American people decided against at the last election; and there are no more inveterate sticklers for the predominance of that party in the whole land." 2 C. WARREN, supra note 18, at 360.

110 See B. WOODWARD \& S. ARMSTRONG, supra note 13, at 342-412 (discussing United States v. Nixon, 418 U.S. 683 (1974) (the Watergate tapes case)); id. at 38-60 (discussing Alexander v. Holmes County Bd. of Educ., 396 U.S. 19, 20 (1969) (per curiam) (holding that "continued operation of segregated schools under a standard of allowing 'all deliberate speed' for desegregation is no longer constitutionally permissible")); see also L. TRIBE, supra note 1, at 37-38 (referring to Chief Justice Warren's role in obtaining a unanimous opinion in Brown v. Board of Educ., 347 U.S. 483 (1954): "That the Court spoke with a single, authoritative voice in Brown added im- 
rewarded with a measure of acceptance that, given the extraordinary controversy surrounding the Court's decisions, undoubtedly exceeded that which would have followed a five-to-four opinion, or, more to the point, a unanimous opinion handed down by nine liberal appointees of the Lyndon Johnson administration. ${ }^{111}$

A more rational allocation of appointment opportunities would enhance the legitimacy of the Court. Rather than representing a threat to judicial independence, it would actually strengthen the Court's ability to perform its most controversial constitutional functions. The threat represented by court packing lies not in the alteration of the appointment process per se, but rather in the purpose and method of its implementation.

\section{Competence}

Before considering alternatives to the current system, brief attention should be paid to a remaining, and obviously essential, concern of the appointment process: ensuring the competence of the Court's membership. ${ }^{112}$ The bulk of the Court's work-granting and denying certiorari, deciding cases, and issuing legal opinions in support of its decisions-presumably calls for personal attributes that more or less correspond to those listed by Henry Abraham: (1) "demonstrated judicial temperament"; (2) "professional expertise and competence"; (3) "absolute personal as well as professional integrity"; (4) "an able, agile, lucid mind"; (5) "appropriate professional educational background

measurably to the ruling's credibility in the face of widespread and bitter resistance.").

Woodward and Armstrong suggest that the unanimity of the Court dissuaded President Nixon from defying its order in the tapes case:

Nixon had seriously contemplated not complying if he lost, or merely turning over excerpts of the tapes or edited transcripts. He had counted on there being some exception for national-security matters, and at least one dissent. He had hoped there would be some "air" in the opinion.

"Unanimous?" Nixon guessed.

"Unanimous," [Chief of Staff Alexander] Haig said. "There is no air in it at all."

"None at all?" Nixon asked.

"It's tight as a drum."

After a few hours spent complaining to his aides about the Court and the Justices, Nixon decided that he had no choice but to comply,

B. Woonward \& S. ARmstrong, supra note 13, at 412 (footnote omitted).

11 But cf. Choper, supra note 43, at 855-56 (noting the difficulties that have accompanied the enforcement of some of the Court's more controversial decisions).

112 See, e.g., The Federalist No. 51, at 321 (J. Madison) (C. Rossiter ed. 1961) (noting that, "peculiar qualifications being essential in the members [of the judiciary], the primary consideration ought to be to select that mode of choice which best secures these qualifications"). 
or training"; and (6) "the ability to communicate clearly, both orally and in writing, especially the latter."113 Accomplishing the Court's basic tasks requires certain institutional attributes as well. In particular, an efficient membership size and organizational structure are essential elements of a competently functioning Court. ${ }^{114}$

Yet the importance of the Court extends beyond its ability to resolve individual controversies. For example, the quality of the reasoning underlying the Court's opinions is important not only to the particular cases at issue but also to related cases that will arise in the future. Diversity of opinion among the Justices may serve to identify relevant arguments and thus to improve the quality of the Court's decisions. ${ }^{115}$ More generally, the Court's disposition of cases helps to shape not only the application of law during the immediate future but also the evolution of legal principles over extended periods of time. In this latter respect, dissenting opinions may play a crucial role in laying the foundations for future legal development. ${ }^{116}$ Finally, the Court's role as a forum for debate may in some cases transcend its function as a decisionmaker. Under such circumstances, the presence of Justices willing to express diverse opinions would have a corresponding value entirely independent of whether those opinions ever receive expression in the decisions of the Court. ${ }^{117}$

113 Abraham, supra note 20, at 286.

114 For discussions of the Court's ability to accomplish its constitutionally mandated tasks, see Estreicher \& Sexton, A Managerial Theory of the Supreme Court's Responsibilities: An Empirical Study, 59 N.Y.U. L. REv. 681 (1984); Kurland \& Hutchinson, The Business of the Supreme Court, O.T. 1982, 50 U. GHI. L. REv. 628 (1983); Note, Of High Designs: A Compendium of Proposals to Reduce the Workload of the Supreme Court, 97 HARv. L. REv. 307 (1983).

115 Justice Brennan, the recent Court's "most prolific dissenter," Brennan: Executions are Illegal, Philadelphia Inquirer, Nov. 19, 1985, at 9, col. 6, defended his role in a recent speech at the Hastings College of the Law: "At the heart of [the dissenter's] function is the critical recognition that vigorous debate improves the final product by forcing the prevailing side to deal with the hardest questions urged by the losing side." "Id. (quoting Justice Brennan).

116 See L. TRIBE, supra note 1, at 36-37:

One Justice can . . . make the difference in . . . broadening the range of acceptable views on the Court or redefining the 'center' by staking out the ground at one end of the ideological spectrum. . . .

... [A] justice who trailblazes an ideological outlook on the Court

normally will not carry the day. But his legacy can influence an entire era.

Cf. Kaufman, supra note 103 , at 84 (quoting with approval Chief Justice Hughes's characterization of dissents as " appeals to the brooding spirit of the law, to the intelligence of another day" ").

117 See Brennan: Executions are Illegal, supra note 115, at 9, col. 6 (quoting Justice Brennan's statement that " '[d]issents contribute to the integrity of the process, not only by directing attention to perceived difficulties . . . but . . . also by contributing to the marketplace of competing ideas" "); see also L. TRIBE, supra note 1, at 27 (referring to the Justices as the "schoolmasters of the Republic" "). 
The current system of appointments, as compared to the alternatives considered in the next part of this Comment, seems adequate for constituting a Court competent to perform its constitutional functions. ${ }^{118}$ In particular, the maintenance of a stable nine-member Court seems to be conducive to the efficient resolution of individual controversies. On the other hand, a system in which at least one new member would join the Court during each presidential term might better promote the success of the Court's less concrete, but no less important, roles as teacher and prophet, without diminishing its capacity to dispose of the disputes brought before it.

\section{Regulating the Frequency of Appointments}

There are a number of alternatives to the existing method of determining when appointment opportunities will arise. One set of solutions would require a significant restructuring of the appointment process. For example, an independent commission or perhaps even the remaining members of the Court could appoint new Justices as the need arose. At the other extreme, the appointment system could be rejected entirely and replaced by the periodic election of the Justices. Finally, one could impose specific qualifications, such as minimum or maximum age restrictions, that would indirectly affect the timing of appointments to the Court.

Many of these alternatives would undermine the Court's independence and competence to an extent that would outweigh any marginal enhancement of the Court's legitimacy. In the following analysis, therefore, I focus on two sets of proposals that would change the timing of appointments directly while leaving the other attributes of the appointment process more or less intact.

\section{A. Appointing Justices for Fixed Terms}

Assuring periodic appointments requires either abandoning the

118 This remark is not intended to address the merits of the various proposals that have been specifically directed toward improving the Court's ability to manage its workload. The Chief Justice, for example, has proposed the addition of a tenth Justice to handle administrative matters, see $Q \mathcal{E} A$ with the Chief Justice, A.B.A. J., Jan. 1985 , at 91,93 , and he and others have debated the merits of creating a national court of appeals that would resolve differences of opinion among the circuits. See, e.g., Estreicher \& Sexton, supra note 114, at 684-96 (suggesting, in place of these structural changes, a "managerial" model of the Court that features a greater reliance on decisionmaking by the lower federal courts); Glekel, supra note 15, at 13, col. 1 (proposing alternatives such as increasing "the number of cases [the Court] disposes of summarily without oral argument and with only short per curiam opinions" and "permitting the [C]ourt to decide some cases in panels of less than nine"). 
conferral of life tenure or changing the size of the Court. Charles Collier proposed the abandonment of life tenure shortly after the courtpacking incident of 1937.118 Under Collier's proposed constitutional amendment, Justices would serve on the Supreme Court for twelve years following their appointment and would then serve on one of the courts of appeals until retirement. ${ }^{120}$ The Court's size would be expanded to include twelve members, so that appointment opportunities would generally arise each year. ${ }^{121}$ If a Justice retired prior to the expiration of the twelve-year period, the President would make a special appointment to fill the remainder of the term. ${ }^{122}$ However, no President would be permitted more than six appointments; any additional appointments would be made by the Justices then sitting on the Court. ${ }^{123}$

A number of problems are evident on the face of Collier's proposal. First, the abandonment of life tenure might compromise the independence of the Court. A number of the specific features of Collier's proposal, including relatively long terms of service, a prohibition on reappointment to the Court, and an opportunity for subsequent service in the appellate courts, tend to mitigate any effects on the Court's independence. ${ }^{124}$ Nevertheless, justices who declined to serve on the courts of appeals would presumably seek other employment at the conclusion of the twelve-year term, ${ }^{125}$ and the prospect of future employment might affect their willingness to make certain determinations while sitting on the Court. ${ }^{128}$

Perhaps a more serious threat to the Court's independence lies in the rapid turnover in membership contemplated under Collier's proposal. A change in one-half of the membership every six years might attune the Court to current political developments to a degree that would inhibit its countermajoritarian function. ${ }^{\mathbf{1 2 7}}$ Any residual appointments

119 See Collier, supra note 14 , at 419 ; $c f$. Elliot, supra note 84 , at $602-03$ (describing other proposals for establishing terms of service).

120 See Collier, supra note 14, at 419-27.

121 See id. at 419-23.

122 See id.

12s See id. at 427-28. Collier advanced his proposal prior to the enactment of the twenty-second amendment, which limits Presidents to no more than two and one-half terms of service. U.S. ConST. amend. XXII, $\S 1$.

124 See Collier, supra note 14, at 419-26. But cf. The Federalist No. 78, at 471 (A. Hamilton) (C. Rossiter ed. 1961) ("Periodical appointments, however regulated, ... . would . . . be fatal to [a judge's] necessary independence.").

${ }^{125}$ Resigning to seek other employment has also occurred under the existing system, but the practice was much more common in the early years of the Court. See McKay, supra note 8, at 122 \& nn.59-63.

${ }^{128}$ See Collier, supra note 14 , at 423-24.

127 Collier clearly intended to increase the political responsiveness of the Court; he 
that were required would increase this rate of change even further. On the other hand, reducing the turnover rate would simply increase the length of the fixed term necessary for maintaining a Court of a given size and thus increase the number of residual appointments likely to be required. ${ }^{228}$ These residual appointees would presumably be subject to political pressure similar to that imposed on judges appointed under the recess appointments clause. ${ }^{129}$ In addition, limitations by reference to particular Presidents, rather than presidential terms, would give insufficient weight to voters that re-elect incumbent Presidents. Similarly, the suggestion that members of the Court occasionally appoint new Justices is inconsistent with a theory of legitimacy substantially based on the representative status of those making appointments. ${ }^{130}$

A system of fixed terms also could reduce the Court's institutional competence. In theory, a limited term of service might attract fewer qualified candidates, ${ }^{131}$ although a sufficiently long term of service and subsequent judicial employment would presumably provide an adequate inducement in most cases. ${ }^{\mathbf{1 3 2}}$ Moreover, to the extent that individual competence is enhanced by experience at the the Supreme Court level, shorter tenure and the use of residual terms may reduce the Court's overall effectiveness. ${ }^{133}$

Finally, the establishment of fixed terms would deny Justices discretion to determine the timing of their own retirements. This change

expressed a desire to avoid "dangerous diversity in purpose and violent collisions of opinion between the federal judiciary and the political branches of government." Id. at 416.

198 For example, one could establish a system in which two appointments per term were used to establish a Court of nine members. The basic length of tenure under this system would be 16 years. Reducing the term to 12 years would require reducing the Court's size to only seven members.

${ }^{128}$ For a discussion of the issues raised by the recess appointments of article III judges, see United States v. Woodley, 751 F.2d 1008 (9th Cir. 1985) (en banc), discussed supra text accompanying notes 50-67.

130 Appointment by the Court may be undesirable for other reasons as well. $C f$. The FEDERalist No. 76 (A. Hamilton) (describing the advantages of vesting the nomination power in a single individual).

131 See The Federalist No. 78, at 471-72 (A. Hamilton) (C. Rossiter ed. 1961) (suggesting that a temporary duration in office would discourage qualified candidates).

${ }_{132}$ The late Justice Potter Stewart, for example, performed part-time service at the circuit court level after his retirement from the Court. See, e.g., Marrese v. American Academy of Orthopaedic Surgeons, 692 F.2d 1083, 1096 (7th Cir. 1982) (Stewart, J., dissenting), modified, 706 F.2d 1488 (7th Cir. 1983), modified on rehearing en banc, 726 F.2d 1150 (7th Cir. 1984), rev'd, 105 S. Ct. 1327 (1985).

${ }^{133}$ See, e.g., Scheb \& Ailshie, Justice Sandra Day O'Connor and the "Freshman Effect," 69 JuDiCATURE 9, 9-12 (1985) (observing that new appointees to the Court often exhibit "uncertainty, disorientation and vacillation"); see also Note, supra note 101 (discussing changes in Justice Blackmun's opinions during his tenure on the Court). 
would eliminate a possible incentive for a Justice to delay retirement despite serious illness or other physical limitations. But the incapacity of a Justice may be addressed directly, without reference to the appointment process, ${ }^{194}$ and preventing the Justices from making their own decisions about retirement would undermine the Court's ability to consider and articulate a full range of views. Without fixed terms, fully capable Justices may remain in office when their political views are in disfavor. Through private persuasion and public dissent, these Justices promote additional diversity of opinion and protect against oppression by political majorities. ${ }^{155}$

Under all of these circumstances, a system based on fixed terms of service would not represent an improvement over the current system. Any gains from rationalizing the timing of appointments would be offset by the potential harm to the independence and competence of the Court.

\section{B. Fixing the Number of Appointments per Term}

The negative effects of irregularly timed appointments might also be addressed through a system in which each presidential term would include a fixed number of appointments. Life tenure would be retained under this approach. As a result, the Court would increase or decrease in size as necessary to accommodate any difference between the rate of retirement and the fixed rate of appointment.

Establishing a range of appointment opportunities, as opposed to mandating a fixed number per term, would diminish the number of required changes in the Court's size. For example, each presidential term could include at least one but no more than three appointments.

Varying the size of the Court through either of these methods, however, may limit the Court's institutional competence in certain respects. The allocation of labor and other available resources might be accomplished more effectively if the Court's size remained relatively stable. Variations in Court size might also reduce the quality of the Court's analysis; smaller groups might represent an insufficient range of opinion, while larger groups might experience greater difficulty in achieving consensus. In addition, reductions in size might impede the Court's efforts to handle its workload.

${ }^{184} C f$. U.S. ConsT. amend. XXV, $\S 4$ (establishing procedures under which the Vice President would assume the responsibilities of Acting President when the President is found "unable to discharge the powers and duties of his office").

1ss See supra notes 115-17 and accompanying text (discussing the role of dissents in shaping the development of the law). 
These concerns are sufficient to outweigh the benefits of adopting either a fixed number or a maximum number of appointments. Establishing a minimum of one appointment per presidential term, however, would on balance improve the appointment process. The operative language of the legislation implementing this change might read as follows:

If there has been no appointment to the Supreme Court during any presidential term as of December 31 of the third year of that term, the President shall forthwith nominate, and by and with the advice and consent of the Senate, shall appoint, an additional Justice of the Supreme Court. The next appointment to the Supreme Court shall not be made until the Court consists of eight Justices or fewer, or until December 31 of the third year of the following presidential term, whichever is sooner. In the event that a new appointment cannot be made following the resignation, retirement, or death of the Chief Justice, the President shall nominate, and by and with the advice and consent of the Senate, shall appoint, a new Chief Justice from among the Justices then sitting on the Court.

In implementing this proposal, the political branches should take care to avoid compromising the Court's legitimacy. Under no circumstances should the enabling legislation become effective until at least five years have elapsed following its enactment. With this delay in implementation, the proposal could be considered largely on its merits-no faction could be sufficiently certain of the outcome to cast votes based on narrow partisan interests. ${ }^{196}$ This type of mechanism, or perhaps resort to the amendment process, could minimize the extent to which the proposal would be viewed as an opportunity for short-term political gain.

The effects of a minimum appointment on the competence of the Court would be relatively slight. Appointments made under this provision could not decrease the size of the Court, and any increases in size would usually last only until the next retirement, resignation, or death of a seated Justice. The proposed system could result in an even-numbered Court and thus reduce the frequency of majority opinions. Nevertheless, even-numbered votes occur occasionally under the existing system and are not in themselves of sufficient concern to outweigh the

${ }^{136}$ Cf. J. Rawls, A Theory of Justice 136-42 (1971) (suggesting the use of a "veil of ignorance" for deciding questions of justice). 
benefits of the proposed change. ${ }^{197}$ Indeed, employing an even number of Justices would permit important constitutional issues to "percolate" in the appellate courts until the Supreme Court has achieved sufficient consensus to reach a decision by at least a two-vote majority. ${ }^{138}$

Fears that this proposal would engender an ever-growing Court are simply unrealistic: the normal rate of change on the Court is generally sufficient to generate at least one appointment per presidential term. ${ }^{139}$ Moreover, the proposed system has a natural tendency to return toward a nine-member equilibrium. All other things being equal, including the average age of appointees and retirees, any increases in the Court's size caused by the proposal will raise the average rate of new vacancies, thus reducing the likelihood of further increases and affording an opportunity for a compensating reduction in the Court's membership. ${ }^{140}$

${ }^{137}$ But of. Collier, supra note 14, at 429-30 (suggesting that affirmances by an equally divided Court nullify the effect of an appeal and lead to a waste of "expense, effort, and argumentation"); Note, Plurality Decisions and Judicial Decisionmaking, 94 HaRv. L. REv. 1127, 1128 (1981) ("The Supreme Court has a role beyond that of resolving individual disputes; it serves as a guide for private parties, legislatures, lower courts, and its own future decisions. In order to perform this function adequately the Court must provide definitive statements of the law.") (footnote omitted).

138 Compare the analysis offered by Professors Estreicher and Sexton:

[M]ore than past practice and the structure of the judicial system supports a policy of awaiting percolation before Supreme Court intervention. . . . The views of the lower courts on a particular legal issue provide the Supreme Court with a means of identifying significant rulings as well as an experimental base and a set of doctrinal materials with which to fashion sound binding law. The occurrence of a conflict acts as a signaling device to help the Court identify important issues. Moreover, the principle of percolation encourages the lower courts to act as responsible agents in the process of development of national law.

Estreicher \& Sexton, supra note 114, at 719 (footnotes omitted).

130 Since 1869, when the Court's current nine-member size was established, United States Presidents have appointed an average of 2.3 Justices per four-year term. See G. GuNTHER, supra note 8, at app. A.

${ }_{140}$ In general, the average number of years between appointments to the Court (Y) equals the average length of service on the Court divided by the number of Justices (N). Average length of service, in turn, equals the difference between the average age at appointment $\left(A_{A}\right)$ and the average age at retirement, resignation, or death $\left(A_{R}\right)$. Thus, $Y=\left(A_{R}-A_{A}\right) / N$. Obviously, if the proposed appointment mechanism were to trigger an increase in the size of the Court $(N)$, the expected number of years between appointments $(\mathrm{Y})$ would decrease, and it would be less likely that further resort to the proposed mechanism would be required.

The average age of the 19 appointees since 1945 has been approximately 55; the average age of the 19 Justices stepping down from the bench during that period has been approximately 68.4. See G. GUNTHER, supra note 8, at app. A. At those rates, one would expect new appointments to take place, on average, every one-and-a-half years $([68.4-55] / 9=1.5)$. The actual rate of appointment has been somewhat slower-23 appointments in the 40 years between 1945 and 1985 (an appointment every 1.74 years) - because a number of the current Justices have delayed retirement 
These two factors-expected average vacancies well in excess of one per term and the self-limiting tendency of the proposed system-should prevent a substantially expanded Court in all but the most extreme case. In such a case-if, for example, a President were able to replace the entire Court with thirty-year-old appointees within a single four-year term ${ }^{141}$ - the especially severe impact on the Court's legitimacy, and ultimately its independence, would justify whatever loss in efficiency would result from a necessary increase in the size of the Court. Indeed, the most important feature of this proposal is its enhancement of the Court's legitimacy in those periods in which this concern is likely to be most important: presidential terms in which voters have had no opportunity-not simply disproportionately little-to influence the personal or philosophical makeup of the Court. ${ }^{142}$ The benefits of the proposal in these periods, as well as the mechanics of its implementation, are best observed through a brief review of its possible historical applications.

\section{RE-PACKING The Court}

Laurence Tribe recently noted the impossibility of knowing for certain what "would have happened" if appointments to the Court had been altered: "But how do we forecast the past? After all, there is usu-

far beyond the average age of the previous 19 retirees. Even if the age of the current Justices reflects a long-term trend toward later retirement, and even if Presidents succeed in appointing somewhat younger Justices, see infra note 141, however, such trends are unlikely soon to increase the average appointment interval above four years. Such an increase would require a dramatic shift in the average length of service on the Court: from 13.4 to more than 36 years of service.

141 A number of commentators have suggested that President Reagan's tendency to nominate relatively young candidates for the federal bench may shape the character of the lower federal courts for many years to come. See, e.g., Podesta, supra note 15, at 4, col. 4 (noting the comments of Professor Herman Schwartz); Roberts, Democrats Judicially Frustrated, N.Y. Times, Nov. 26, 1985, at A20, col. 4 (noting the comments of Senator Mathias). But see Goldman, supra note 15, at 323 (finding that the "average age of the Reagan appointees was about that of the Carter appointees and similar to that of the appointees of the previous three presidents").

At some point political pressures would restrict a President's ability to appoint large numbers of young, politically compatible judges, particularly at the Supreme Court level, where appointments are subject to far greater press coverage and general public interest. Even if the President's party controlled the Senate when the nine successive appointments arose, it would be virtually impossible for the President to succeed in appointing young men and women to all of these positions.

112 The appointment of even a single Justice may have a profound effect on the direction of the Court. See L. TRIBE, supra note 1, at 31-40 (noting, in particular, swings in important five-to-four votes, the creation of a "critical mass" that alters a delicate ideological balance, the articulation of divergent views that redefine the "center" of the Court's positions, and the provision of influential leadership in the role of Chief Justice). 
ally no way to know which person would have been nominated for a seat on the Court if the person ultimately selected had been passed over."143 This observation is no less true with respect to the current exercise. Any actual uses of the proposal would have altered the subsequent timing of appointments to the Court in unpredictable ways, and it is therefore impossible to re-create the altered historical sequence of appointments.

Despite such limitations, a few significant conclusions may be drawn from the historical record. A useful, if not completely precise, suggestion of the effects of the proposal may be illustrated simply by focusing on the particular presidential terms in which no appointments were made.

The early days of the Court would have passed without any applications of the proposal. President Washington's appointees served for relatively short terms, and the rate of new appointments to the Court was therefore entirely sufficient. By the second term of the Madison administration, however, the relatively low rate of appointments arising for a seven-member Court would have triggered an additional appointment. ${ }^{144}$ The Court would thus have risen in size from seven to eight members, and then from eight to nine members during the first term of the Monroe administration. The Court would have returned to its seven-member size during the course of Andrew Jackson's two terms in office.

The next application of the proposal would have occurred during Andrew Johnson's administration. As explained in Part I of this Comment, Johnson was presented with a vacancy on the Gourt, but the position was eliminated by a hostile Congress. ${ }^{145}$ Assume for purposes of this discussion, however, that Johnson's lack of an appointment arose as a natural consequence of the appointment process. At first glance, application of the proposal would have only exacerbated the problems of the Court at that time: the Congress that manipulated appointments and passed the Habeas Corpus Act of 1867 would presumably have increased, rather than tempered, its hostility toward a Court with a Johnson appointee. At second glance, however, the record is far less clear. In view of the Republican control of the Senate at that time, Johnson could not have succeeded in appointing a Democratic politico. He would have been a moderate in the eyes of the Senate and perhaps

143 Id. at 34.

${ }^{144}$ Madison chose both of his appointees, Justices Duvall and Story, during his first term. See G. GuNTHER, supra note 8, at app. A.

${ }^{145}$ See 2 C. WARREN, supra note 18 , at 421-22; see also supra text accompanying notes $26-29$. 
an individual of considerable stature in the legal community. Such a Justice might have been more than capable of resisting at least some of the enormous pressure placed on the Court at that time. ${ }^{146}$

Moreover, under the proposed system, Johnson's appointment would have replaced one of the initial appointments of the Grant administration. This shift may have mitigated the perception-whether or not accurate-that the Court, with the addition of Grant's new appointees, acted in effect as representatives of the executive in voting so hastily to reverse its legal tender decision. ${ }^{\mathbf{1 4 7}}$

The proposal would next have been triggered during the second term of Woodrow Wilson. As a result, Wilson would have received one more, and President Harding, one fewer, appointment. If Wilson had appointed another Brandeis, and Harding had forgone the appointment of Sutherland or Butler, the balance of the Court may have shifted to prevent the constitutional showdown of 1937.

The proposed appointment mechanism also would have given Franklin Roosevelt an appointment during his first term. The image of the Court that Roosevelt hoped to foster in 1937-that of aged, out-oftouch Justices, representing not even a generalized Burkean notion of consensus $^{148}$ - may have been harder to sustain had there been at least one appointment during the dramatic changes of the New Deal.

The final application is the one that prompted the writing of this Comment. If the proposal had been in place in 1976, President Carter would have appointed a tenth member of the Court during 1980. Fol-

148 Indeed, prior to the statutory elimination of the vacancy on the Court, Johnson nominated Republican Henry Stanbery of Ohio, who should have been more or less acceptable to Johnson's opponents in the Senate. See 2 C. WARREN, supra note 18, at 422. "The Senate, however, was determined to curb the President in every move . . . and fear[ed] that he might have the opportunity to make further appointments to the Bench . . . " Id; $c f$. L. TRIBE, supra note 1, at 91-92 ("[T] he Radical Republicans in all probability would not have confirmed Solomon himself had Johnson named him to serve on the Court.").

${ }^{147}$ Charles Warren quotes a particularly vehement account from the New York World: "The decision provokes the indignant contempt of thinking men. It is generally regarded not as the solemn adjudication of an upright and impartial tribunal, but as a base compliance with Executive instructions by creatures of the President placed upon the Bench to carry out his instructions." " 2 C. WARREN, supra note 18, at 526.

${ }^{148}$ In his initial message in support of the 1937 plan, Roosevelt asserted that

"[1]ife tenure of judges, assured by the Constitution, was designed to place the courts beyond temptations or influence which might impair their judgments; it was not intended to create a static judiciary. A constant and systematic addition of younger blood will vitalize the courts and better equip them to recognize and apply essential concepts of justice in the light of the needs and the facts of an ever-changing world."

L. Pfeffere, supra note 39, at 314 (quoting Roosevelt); see also supra note 80 (describing Burke's notion of an intergenerational consensus). 
lowing the retirement of Justice Stewart in 1981, the Court once again would have consisted of nine members-no additional appointments would have been made at that time. In 1984, however, President Reagan would have completed three years of his first term without an opportunity to make an appointment to the Court. The minimum-appointment provision would take effect once again, and President Reagan would have made an appointment. The Court would then consist of ten members. If more than one Justice retired during Reagan's second term, the Court would return to its usual size. President Reagan would eventually have one appointment fewer, and President Carter one more, than each would have under the existing system.

Some degree of speculation underlies each of these examples. Even the most recent and likely of these projections-that President Reagan would make a disproportionately large number of appointments to the Court-may never come to pass. Nevertheless, the historical record outlined above strongly suggests that an adjustment in the timing of appointments would strengthen the independence and legitimacy of the Court. Such a change, enacted now, may permit the Court to withstand even more serious challenges in future years.

\section{CoNCLUSION}

The proposal made in this Comment is, in effect, a court-packing plan. Indeed, the only truly substantial difference between this plan and past court-packing schemes is a difference in motivation. Unlike the 1937 plan, for example, this proposal presupposes no particular political configuration at the time of its enactment. On the contrary, the suspension of the' proposal's effective date should adequately protect against attempts to use the proposal to advance a partisan political agenda. The true test of the plan, in the end, would be the legitimacy and efficacy of its appointment allocation over a long period of time and in a wide variety of political situations.

A difference in motivation would normally be an all-too-slender thread on which to hang such a proposal's success. But the failings of the current appointment process, while not always immediately evident, may not safely be ignored. From the reversal of the legal tender decision to the recent concern with the replacements for an aging Court, an examination of the Court's past suggests that the realignment of even a few appointments might have had a profound effect on some of the most important moments in our nation's history. Adjusting the frequency of appointments may determine the very survival of our constitutional system, or it may affect something as "unimportant" as the conviction of a single criminal defendant. In either event, the stakes are 
too high to permit an unquestioned adherence to a long-standing but illogical tradition. 